\begin{tabular}{l|l|l} 
Jurnal Eksplorasi Akuntansi & $\begin{array}{l}\text { ISSN : 2656-3649 (Online) } \\
\text { hol 2, No 4, Seri D, November 2020, Hal 3688-370a.ppj.unp.ac.id/index.php/jea/issue/view/32 }\end{array}$
\end{tabular}

\title{
Pengaruh Struktur Kepemilikan Dan Karakteristik CFO Terhadap Konservatisme Akuntansi
}

(Studi Empiris Pada Perusahaan Manufaktur yang Terdaftar di Bursa Efek Indonesia

Tahun 2015-2018)

\author{
Peni Aliza ${ }^{1}$, Vanica Serly ${ }^{2}$ \\ ${ }^{1}$ Alumni Jurusan Akuntansi Fakultas Ekonomi Universitas Negeri Padang \\ 2Jurusan Akuntansi Fakultas Ekonomi Universitas Negeri Padang \\ *Korespondensi: Penializa1622@gmail.com
}

\begin{abstract}
In Indonesia, there are cases of failure in the application of accounting conservatism in manufacturing companies, one of which is PT. Tiga Pilar Sejahtera Food Tbk. which made a mistake in the presentation of financial statements. This error resulted in overstated profits in the year ended December 31, 2017. This indicates a failure in the application of accounting conservatism in manufacturing companies due to carelessness and management's interest in presenting financial statements, resulting in overstated net income. In this case, the company is considered to have excessive optimism in recognizing profit, which causes the value of profit to be greater than it should be. This study aims to see the effect of ownership structure and CFO characteristics on accounting conservatism in manufacturing companies listed on the Indonesia Stock Exchange for the period 2014-2018. This type of research is quantitative. The population used in this study are manufacturing companies listed on the Indonesia Stock Exchange (IDX) with a total sample of 112 samples using purposive sampling method. The analysis was performed using multiple regression models. The results of this study indicate that: (1) Managerial ownership has a negative but insignificant effect on accounting conservatism with a significance level of 0.564. (2) Institutional ownership has a positive and significant effect on accounting conservatism with a significance level of 0.291. (3) The tenure of CFO has a positive and insignificant effect on accounting conservatism with a significance level of 0.804
\end{abstract}

Keywords: CFO Tenure;Institusional ownership;Managerial Ownership

How to cite (APA $6^{\text {th }}$ style):

Aliza, P \& Serly, V. Pengaruh Struktur Kepemilikan dan Karakteristik CFO terhadap Konservatisme Akuntansi (Studi Empiris Pada Perusahaan Manufaktur yang Terdaftar di Bursa Efek Indonesia Tahun 2015-2018). Jurnal Eksplorasi Akuntansi. 2(4), Seri D, 3688-3704.

\section{PENDAHULUAN}

Di Indonesia terdapat kasus kegagalan penerapan konservatisme akuntansi di perusahaan manufaktur, salah satunya adalah PT. Tiga Pilar Sejahtera Food Tbk. (AISA Group) yang 
melakukan kesalahan dalam penyajian laporan keuangan. Kesalahan tersebut mengakibatkan overstated (kenaikan) laba pada tahun yang berakhir 31 Desember 2017 sebesar Rp. 4 Triliun, kenaikan laba merupakan penggelembungan pada akun piutang usaha, persediaan, dan aset tetap, serta pendapatan dari hasil penjualan sebesar Rp. 662 Miliar pada entitas bisnis makanan dan penggelembungan pada pos EBITDA (Laba sebelum bunga, pajak, depresiasi, dan amortisasi) senilai Rp. 329 Miliar. Pada pos transaksi juga terdapat aliran dana Rp. 1,78 triliun melalui berbagai skema dari Grup AISA kepada pihak yang di duga terafiliasi dengan manajemen lama namun tidak menggunakan pengungkapan (disclosure) yang memadai kepada stakeholders secara relevan (CNBC Indonesia.com).

Kasus yang terjadi pada PT. Tiga Pilar Sejahtera Food Tbk. menunjukkan adanya kegagalan dalam penerapan konservatisme akuntansi pada perusahaan manufaktur dikarenakan adanya ketidakhati-hatian serta kepentingan manajemen dalam penyajian laporan keuangan sehingga terjadi overstated pada laba bersih. Di dalam hal ini perusahaan dinilai memiliki optimisme yang berlebihan dalam mengakui laba, sehingga menyebabkan nilai laba menjadi lebih besar dari yang seharusnya.

Perusahaan menggunakan prinsip konservatisme sebagai salah satu bentuk pertimbangan dalam perlakuan akuntansi dan laporan keuangan, karena aktivitas perusahaan yang beragam sehingga dilingkupi dengan ketidakpastian. Sehingga, dengan menerapkan prinsip konservatisme akuntansi dalam melakukan pengukuran dan penilaian akuntansi dapat membatasi sikap oppurtunistik manajemen (Alkurdi et al., 2017). Konservatisme merupakan prinsip penyajian informasi keuangan yang dihadapkan pada prinsip kehati-hatian, yaitu pencatatan pendapatan dan biaya, maupun pencatatan terhadap aset. Implementasi atas asas konservatisme yaitu jika terdapat suatu yang dapat meningkatkan aset, tetapi belum terealisasi, maka kejadian tersebut belum boleh diakui. Akan tetapi jika terdapat sesuatu yang megakibatkan penurunan aset, walaupun belum terealisasi maka kejadian itu harus sudah diakui oleh perusahaan (Nasir dkk, 2014).

Konservatisme dapat dijelaskan dalam perspektif teori keagenan. Dalam teori keagenan terdapat pemisahan antara pihak agen dan prinsipal. Hal tersebut dapat berakibat pada munculnya potensi konflik yang dapat mempengaruhi kualitas laba yang dilaporkan. Pihak manajemen yang mempunyai tujuan tertentu misalnya dalam mendapatkan bonus cenderung akan menyusun laporan keuangan dengan angka laba yang lebih besar. Oleh karena itu, perusahaan dapat mencegah hal tersebut dengan menerapkan konservatisme akuntansi dalam penyusunan laporan keuangan (Brilianti, 2013).

Penerapan konservatisme akuntansi dalam perusahaan dapat dipengaruhi beberapa faktor, diantaranya yaitu struktur kepemilikan. Struktur kepemilikan perusahaan dapat dibagi menjadi dua yaitu struktur kepemilikan manajerial dan struktur kepemilikan institusional (Astuti, 2007). Struktur kepemilikan manajerial merupakan kepemilikan saham terbesar oleh manajemen perusahaan yang diukur dengan persentase jumlah saham yang dimiliki manajemen. Sedangkan struktur kepemilikan institusional adalah saham dalam suatu perusahaan publik yang dimiliki oleh perusahaan besar lainnya, bank, institusi-institusi tertentu yang dapat mengontrol operasi atau kebijakan perusahaan (Wulansari \& Riduwan, 2014).

Kepemilikan manajerial memberikan pengaruh dalam perusahaan, karena dengan adanya kepemilikan manajer terhadap saham perusahaan akan menimbulkan rasa kepemilikan pada perusahaan, sehingga manajemen akan cenderung menerapkan akuntansi yang lebih konservatif. Semakin tinggi tingkat kepemilikan saham di dalam perusahaan oleh manajer maka laporan keuangan yang dibuat akan lebih konservatif karena manajer tidak lagi hanya berperan sebagai agen namun juga sebagai pemilik saham (R.Padmawati \& Fachrurrozie, 2015).

Penelitian Pambudi (2017), pada perusahaan manufaktur di Indonesia menunjukkan bahwa 
kepemilikan manajerial berpengaruh positif terhadap konservatisme akuntansi. Namun bertolak belakang dengan penelitian yang dilakukan oleh Wulansari dan Riduwan (2014), yang menemukan hasil bahwa, kepemilikan manajerial tidak berpengaruh terhadap konservatisme akuntansi. Hal ini mungkin disebabkan karena manajemen cenderung untuk memilih metode akuntansi yang dapat memaksimalkan utilitasnya demi mendapatkan bonus yang lebih besar, sehingga manajemen terfokus pada hal tersebut. Walaupun manajemen memiliki atau tidak memiliki kepemilikan saham pada perusahaan, mereka akan lebih cenderung memilih metode perlakuan akuntansi yang dapat memaksimalkan bonus yang akan mereka dapatkan.

Kepemilikan institusional merupakan salah satu elemen yang efektif dari kontrol eksternal atas tata kelola perusahaan (Alkurdi et al., 2017). Adanya kepemilikan institusional di suatu perusahaan akan mendorong peningkatan pengawasan, agar kinerja manajer dalam mengelola perusahaan lebih optimal.. Hal ini di dukung oleh penelitian Rachmawati dan Triatmoko (2007), menemukan hasil bahwa, dalam hubungannya dengan fungsi pengawasan, investor institusional diyakini memiliki kemampuan untuk mengawasi tindakan manajemen lebih baik dibandingkan investor individual.

Investor institusional lebih terfokus pada laba masa mendatang (future earnings) yang relatif lebih besar dibandingkan laba sekarang. Investor institusional tergolong pada investor yang berpengalaman (sophisticated) sehingga mereka akan melakukan pengawasan secara efektif dan lebih skeptis terhadap tindakan dari manajemen. Proporsi kepemilikan institusional yang besar diharapkan dapat meningkatkan fungsi pengawasan terhadap kinerja manajemen dan mendorong manajemen untuk menerapkan prinsip akuntansi konservatif (Putra dkk, 2019).

Penelitian Alkurdi (2017), pada perusahaan industri dan keuangan di Yordania menunjukkan bahwa, kepemilikan institusional berpegaruh positif terhadap penerapan konservatisme akuntansi. Hal ini disebabkan karena, dengan adanya kepemilikan institusional di dalam perusahaan akan mendorong peningkatan pengawasan tata kelola perusahaan, sehingga kinerja manajer akan lebih optimal. Namun, bertolak belakang dengan penelitian yang dilakukan oleh Wulansari dan Riduwan (2014), yang menyatakan bahwa kepemilikan institusional tidak berpengaruh terhadap konservatisme akuntansi.

Faktor lain yang mempengaruhi penerapan konservatisme akuntansi pada perusahaan adalah karakteristik Chief Financial Officer (CFO). Karakteristik CFO yang menjadi variabel dalam penelitian ini adalah masa jabatan CFO. Masa jabatan CFO mencerminkan jangka waktu sebuah proses dalam memahami lingkungan eksternal dan internal perusahaan (Milana \& Maldaon, 2015). CFO dengan masa jabatan lebih lama memiliki pengetahuan unik tentang perusahaan sehingga mereka tidak menunda informasi kerugian yang akan terjadi dan memastikan standar verifikasi yang lebih tinggi untuk pengakuan keuntungan atau laba yang diperoleh.

Masa jabatan CFO dapat membantu perusahaan dalam meningkatkan reputasi perusahaan di pasar. Masa jabatan CFO merupakan indikator bahwa CFO memiliki kinerja yang sangat baik, dengan begitu CFO akan memiliki tingkat kepedulian yang lebih tinggi terhadap reputasi mereka. CFO cenderung akan melindungi reputasi yang mereka miliki dari hal-hal yang nantinya akan memperburuk kinerja mereka di hadapan stakeholders dan pemegang saham (Milbourn, 2003).

Pengakuan kabar baik dalam laporan keuangan dapat mempengaruhi reputasi CFO, Hal tersebut dapat memotivasi CFO untuk menghindari praktik akuntansi yang agresif. Namun, pendapat lain menjelaskan bahwa CFO dengan masa jabatan lebih lama akan memiliki sikap oppurtunistic yang lebih tinggi dan memungkinkan mereka untuk memilih praktik akuntansi yang lebih agresif yang tidak memenuhi standar verifikasi untuk mengakui kabar baik dalam penyusunan laporan keuangan (Morck et al., 1989). 
Berdasarkan hasil yang berbeda dan fenomena yang terjadi di Indonesia, penulis tertarik untuk melakukan penelitian kembali. Penelitian ini akan mengacu pada penelitian yang telah dilakukan oleh Alkurdi et al (2017). Perbedaan penelitian ini dari penelitian sebelumnya adalah: pertama terletak pada periode penelitian yang dilakukan. Penelitian ini menggunakan periode 2014-2018 sedangkan penelitian sebelumnya menggunakan periode 2005-2013. Kedua, dalam penelitian ini peneliti menggunakan variabel baru yaitu, masa jabatan CFO.

\section{RIVIW LITERATUR DAN HIPOTESIS}

\section{Teori Keagenan (Agency Theory)}

Teori agensi menjelaskan hubungan kontraktual antara dua pihak atau lebih dimana satu pihak disebut prinsipal dan pihak lain disebut agen. Hubungan prinsipal dan agen sering ditentukan dengan angka akuntansi. Hal ini memicu agen untuk memikirkan bagaimana hal tersebut dapat digunakan sebagai sarana untuk memaksimalkan kepentingannya. Hubungan keagenan adalah suatu kontrak antara satu atau lebih pihak yang mempekerjakan pihak lain untuk melakukan suatu jasa demi kepentingan mereka yang meliputi pendelegasian beberapa kekuasaan pengambilan keputusan kepada pihak lain tersebut (Jensen \& Meckling, 1976). Dengan demikian teori ini mengindikasikan adanya kepentingan pada setiap pihak yang ada pada perusahaan untuk mencapai tujuannya.

Perusahaan yang menerapkan prinsip konservatisme dalam penyusunan laporan keuangan, dapat mengurangi manipulasi laporan keuangan yang dilakukan oleh manajer dan biaya agensi yang muncul akibat asimetri informasi. Perilaku manipulasi yang sering ditemukan dalam teori keagenan adalah pencatatan laba yang overstated. Tindakan ini disebabkan, karena adanya insentif manajemen berupa bonus yang diukur dari kinerja manajemen dalam menghasilkan laba, sehingga mendorong manajer melaporkan laba yang tidak konservatif. Oleh karena itu, manajer cenderung memilih menggunakan metode akuntansi yang dapat memanipulasi laporan keuangan (Tazkiya, 2019).

Dengan adanya pemberian insentif berupa bonus yang diberikan kepada manajer atas pencapaian laba dan kinerja yang dinilai baik oleh pemegang saham, manajer akan meningkatkan laba dengan memanipulasi laporan keuangan dan melakukan praktik manajemen laba. Hal ini dapat disimpulkan bahwa terdapat hubungan antara teori keagenan dengan penelitian ini, yaitu

jika perusahaan menerapkan prinsip konservatisme dalam penyusunan laporan keuangan, maka dapat mencegah tindakan manajer agar tidak melakukan tindakan manipulasi terhadap laporan keuangan.

\section{Konservatisme Akuntansi}

Konservatisme akuntansi merupakan verifikasi tingkat keuntungan yang lebih tinggi daripada tingkat kerugian berdasarkan kebijakan akuntansi konservatisme yang berlaku dalam perusahaan (Alkurdi et al., 2017). Konservatisme merupakan prinsip kehati-hatian dalam menyajikan angka pada laporan keuangan dengan tidak mengantisipasi keuntungan sebagai berita baik melainkan mengantisipasi semua kerugian sebagai berita buruk sehingga angka laba dan aset cenderung rendah, serta angka-angka biaya dan utang cenderung tinggi (Mamesah et al., 2016). The conservatism principle merupakan prinsip pengecualian atau prinsip yang mengubah konsensus umum. Menurut prinsip ini, apabila kita dihadapkan untuk memilih diantara dua atau lebih prinsip/teknik akuntansi yang sama-sama diterima, kita harus megutamakan pilihan yang memberikan pengaruh keuntungan paling kecil pada equity pemilik (Harahap, 2008). yang diminta untuk pengakuan keuntungan dibandingkan kerugian.

Menurut Soewardjono (2005) konservatisme adalah sikap atau aliran mahzab dalam 
menghadapi ketidakpastian, untuk mengambil tindakan atau keputusan atas dasar munculnya (outcome) yang terjelek dari ketidakpastian tersebut. konservatisme akuntansi adalah suatu sikap atau perilaku manajemen dalam menyikapi kondisi ketidakpastian keadaan ekonomi dimasa yang akan datang. Pihak manajemen akan melaporkan aset pada nilai terendah dan melaporkan kewajiban pada nilai tertinggi. Implikasi dari konsep konservatisme terhadap prinsip akuntansi yaitu mengakui biaya dan rugi sesegera mungkin dan menunda pegakuan terhadap laba atau pendapatan. Semakin tinggi tingkat konservatisme laporan keuangan yang disajikan oleh manajer, dapat membantu pihak yang berkepentingan dalam pengambilan keputusan yang lebih tepat.

\section{Kepemilikan Manajerial}

Kepemilikan manajerial adalah kondisi dimana manajer memiliki saham perusahaan sekaligus sebagai pemegang saham perusahaan. Kepemilikan saham oleh manajerial yang tinggi akan mempengaruhi derajat kesamaan kepentingan antara pemilik dengan manajemen (Gandhes, 2018). Menurut Christiawan \& Tarigan ( 2007) dalam Alfian \& Sabeni (2013), kepemilikan manajerial merupakan kepemilikan saham perusahaan oleh manajemen (komisaris, direksi, dan karyawan) atau dengan kata lain manajemen tersebut sekaligus sebagai pemegang saham. Semakin tinggi tingkat kepemilikan saham di dalam perusahaan oleh manajer maka laporan keuangan yang dibuat akan lebih konservatif karena manajer tidak lagi hanya berperan sebagai agen namun juga sebagai pemilik saham (R.Padmawati \& Fachrurrozie, 2015). Semakin tinggi kepemilikan manajerial, maka manajemen bukan hanya sekedar menjadi agen, namun juga menjadi pemilik dari perusahaan dan hal ini dapat mengurangi konflik agensi (Susiana \& Herawaty, 2007, dalam Alfian \& Sabeni, 2013).

Kepemilikan manajerial dalam penelitian ini merupakan kepemilikan saham perusahaan oleh manajemen dari jumlah saham beredar, yang diukur dari persentase jumlah saham yang dimiliki oleh manajer. Kepemilikan saham oleh manajerial yang tinggi akan mempengaruhi

derajat kesamaan kepentingan antara pemilik dengan manajemen. Semakin tinggi tingkat kepemilikan saham manajer di dalam perusahaan, maka laporan keuangan yang dibuat akan lebih konservatif dan diselaraskan dengan kepentingan pemilik karena manajer tidak lagi hanya berperan sebagai agen namun juga sebagai pemilik saham. Namun sebaliknya, semakin rendah tingkat kepemilikan manajer dalam sebuah perusahaan maka laporan keuangan yang dibuat akan cenderung selaras dengan kepentingan pribadinya dan tidak konservatif.

\section{Kepemilikan Institusional}

Kepemilikan institusional merupakan salah satu elemen yang efektif dari kontrol eksternal atas tata kelola perusahaan (Alkurdi et al., 2017). Hal ini di dukung oleh penelitian Rachmawati dan Triatmoko (2007), menemukan hasil bahwa, dalam hubungannya dengan fungsi pengawasan, investor institusional diyakini memiliki kemampuan untuk mengawasi tindakan manajemen lebih baik dibandingkan investor individual. Proporsi kepemilikan institusional yang besar diharapkan dapat meningkatkan fungsi pengawasan terhadap kinerja manajemen dan mendorong manajemen untuk menerapkan prinsip akuntansi konservatif (Putra dkk, 2019). Pemilik institusional dapat mengawasai manajer dalam menjalankan tugasnya. sehingga kinerja perusahaan dapat berjalan dengan baik (Wulansari \& Riduwan, 2014).

Struktur kepemilikan institusional adalah jumlah saham yang dimiliki oleh pihak institusi dibandingkan dengan total jumlah saham yang beredar sehingga dengan kepemilikan saham oleh pihak institusi lain dapat membantu pengawasan yang lebih intensif terhadap perusahaan agar kinerja perusahaan dapat meningkat dan berkelanjutan. Semakin besar proporsi kepemilikan saham institusional pada perusahaan maka tingkat penerapan prinsip konservatisme akan semakin 
konservatif, karena dengan adanya investor institusional dapat lebih mengarahkan tindakan manajemen untuk menerapkan prinsip akuntansi yang konservatif dengan tujuan untuk menghindarkan tindakan oportunis manajemen untuk memanipulasi kinerja perusahaan atau laporan keuangan yang disajikan setiap akhir periode begitupun sebaliknya.

\section{Masa Jabatan CFO}

Masa jabatan CFO mencerminkan jangka waktu atau sebuah proses dalam memahami lingkungan eksternal dan internal perusahaan (Milana \& Maldaon, 2015). Masa jabatan CFO merupakan indikator bahwa CFO memiliki kinerja yang sangat baik, dengan begitu CFO akan memiliki tingkat kepedulian yang lebih tinggi terhadap reputasi mereka. CFO cenderung akan melindungi reputasi yang mereka miliki dari hal-hal yang nantinya akan memperburuk kinerja mereka di hadapan stakeholders dan pemegang saham (Milbourn, 2003). Masa jabatan CFO adalah masa kerja yang dimiliki oleh CFO dalam mengelola keuangan perusahaan. CFO yang memiliki masa jabatan lebih lama akan cenderung lebih berkomitmen dalam menerapkan prinsip konservatisme dibandingkan dengan CFO yang memiliki masa kerja lebih pendek, karena CFO dengan masa jabatan lebih lama memiliki pengetahuan yang lebih mengenai konteks pekerjaan dan perusahaan secara spesifik, sehingga akan cenderung lebih berkomitmen untuk membuat laporan keuangan yang lebih konservatif.

\section{Pengaruh Kepemilikan Manajerial terhadap Konservatisme Akuntansi}

Berdasarkan teori agensi, semakin besar kepemilikan oleh inside directors (kepemilikan manajerial), maka akan mengarahkan pada keselarasan tujuan antara pihak manajemen dengan pemegang saham (Wardhani, 2008). Penelitian selanjutnya dilakukan oleh Putra dkk (2019), menyatakan bahwa kepemilikan manajerial berpengaruh signifikan positif terhadap konservatisme akuntansi. Perusahaan yang memiliki tingkat kepemilikan manajerial yang tinggi menunjukkan pola yang lebih konservatif dalam pelaporan pendapatannya dibandingkan dengan perusahaan yang memiliki tingkat kepemilikan manajerial yang rendah. Penelitian yang dilakukan oleh Pambudi (2017), hasil penelitian menunjukkan bahwa kepemilikan manajerial berpengaruh positif terhadap konservatisme akuntansi. Apabila kepemilikan saham yang dimiliki seorang manajer dalam perusahaan tinggi, maka perusahaan akan semakin menerapkan prinsip akuntansi yang konservatif.

Dari hasil penelitian yang dilakukan oleh peneliti sebelumnya maka penulis berpendapat bahwa semakin tinggi tingkat kepemilikan saham manajerial, maka penerapan prinsip konservatisme dalam penyusunan laporan keuangan akan semakin konservatif pula. Dengan adanya kepemilikan manajerial mendorong manajemen untuk memaksimalkan kinerjanya dalam bentuk penyusunan laporan keuangan perusahaan yang lebih konservatif. Ketika manajemen memiliki motivasi untuk meningkatkan kinerja perusahaan, maka akan lebih berhati-hati dalam menentukan kebijakan akuntansi. Maka hipotesis pertama dalam penelitian ini adalah:

H1: Kepemilikan manajerial berpengaruh signifikan positif terhadap konservatisme akuntansi.

\section{Pengaruh Kepemilikan Institusional terhadap Konservatisme Akuntansi}

Berdasarkan teori keagenan, perusahaan akan semakin menerapkan prinsip akuntansi yang konservatif apabila kepemilikan saham yang dimiliki oleh pihak institusional tinggi. Penelitian Fama \& Jensen (1983), menganjurkan suatu mekanisme pengawasan untuk mengatasi masalah keagenan. Salah satu mekanisme pengawasan tersebut dengan mengaktifkan monitoring melalui investor-investor institusional. Dengan kepemilikan institusional oleh perusahaan investasi, bank, perusahaan asuransi maupun berupa kepemilikan lembaga lain seperti perusahaan perusahaan 
akan mendorong munculnya pengawasan yang lebih optimal terhadap kinerja manajer. Penelitian yang dilakukan oleh Alkurdi et al (2017) hasil penelitian menunjukkan adanya pengaruh positif yang signifikan antara kepemilikan institusional dengan konervatisme akuntansi. Kepemilikan institusional yang tinggi dapat meningkatkan pengawasan terhadap kinerja manajer dalam mengelola perusahaan, sehingga mendorong manajer menerapkan prinsip akuntansi yang lebih konservatif.

Penelitian serupa juga dilakukan oleh Putra dkk (2019), temuan penelitiannya yaitu kepemilikan institusional berpengaruh positif terhadap konservatisme akuntansi. Semakin besar tingkat kepemilikan institusional pada perusahaan maka semakin konservatif pula penerapan prinsip konservatisme akuntansi dalam penyusunan laporan keuangan. Dari hasil penelitian yang telah dilakukan oleh beberapa peneliti sebelumnya, maka penulis berpendapat bahwa semakin tinggi tingkat kepemilikan institusional dalam perusahaan, maka akan semakin tinggi pula penerapan prinsip konservatisme akuntansi dalam penyusunan laporan keuangan. Hal ini disebabkan karena dengan adanya pengawasan yang tinggi dari pihak institusional terhadap kinerja manajer dapat mendorong manajer untuk menerapkan prinsip akuntansi yang lebih konservatif. Maka hipotesis kedua dalam penelitian ini adalah:

H2: Kepemilikan Institusional berpengaruh signifikan positif terhadap konservatisme akuntansi.

\section{Pengaruh Masa Jabatan CFO terhadap Konservatisme Akuntansi}

Lamanya masa jabatan CFO dapat meningkatkan keahlian dan pengetahuan tentang perusahaan, sehigga dapat membantunya untuk lebih memahami sistem pelaporan keuangan perusahaan dan dapat mengkomunikasikan informasi keuangan secara lebih efektif kepada para pemangku kepentingan eksternal (Muttakin et al., 2019). Hasil dari beberapa penelitian terdahulu Muttakin et al (2019), pada perusahaan non-keuangan yang terdaftar di ASX selama periode 2001-2014. Hasil penelitian menyatakan bahwa masa jabatan CFO berpengaruh positif pada konservatisme akuntansi. Sedangkan, Ali \& Zhang (2015) menemukan hasil bahwa masa jabatan CFO berpengaruh terhadap konservatisme akuntansi. Geiger et al (2008), menemukan hasil bahwa masa jabatan CFO memiliki pengaruh terhadap konservatisme akuntansi.

Perusahaan dengan masa jabatan CFO yang lebih pendek akan cenderung menyajikan laporan keuangan dengan kesan lebih menguntungkan di pasar sehingga mereka dapat mempertahankan jabatan yang mereka miliki, Sedangkan CFO yang memiliki masa jabatan lebih lama akan lebih tertarik untuk melindungi reputasi mereka. Masa jabatan CFO akan mendorong mereka untuk mempercepat pengakuan goodnews dari pada badnews sehingga mengurangi tingkat konservatif, karena akan mempengaruhi masa jabatan atau kompensasi yang mereka miliki. Maka hipotesis ke-tiga dalam penelitian ini adalah:

H3: Masa jabatan CFO berpengaruh signifikan positif terhadap konservatisme akuntansi. .

\section{Kerangka Konseptual}

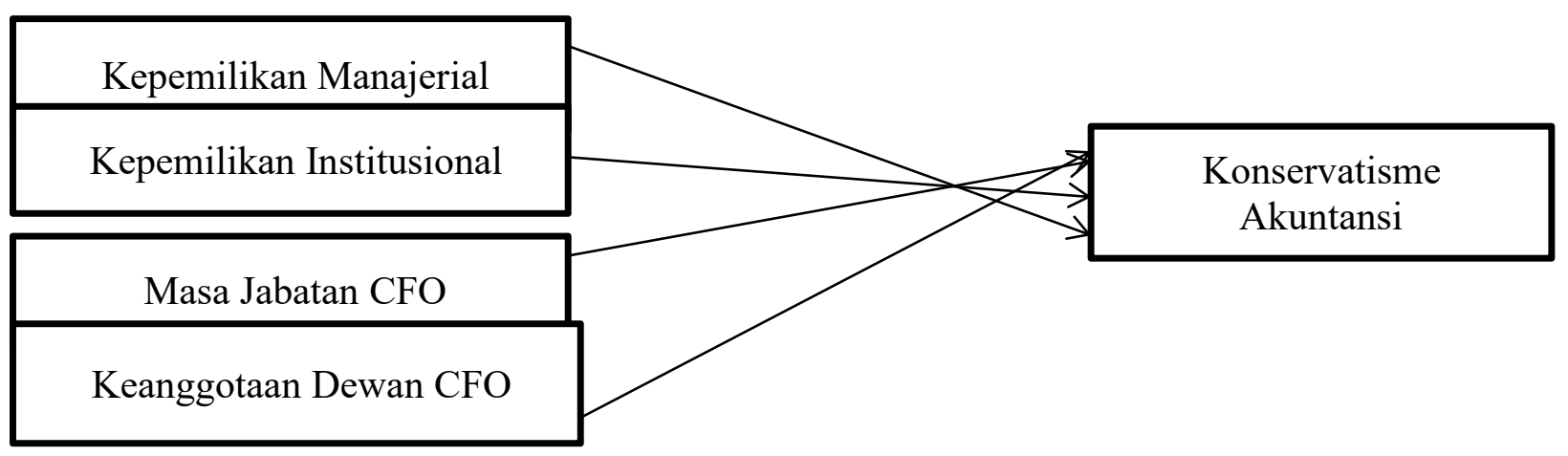




\section{METODE PENELITIAN}

\section{Jenis, Populasi dan Sampel Penelitian}

Jenis penelitian yang digunakan adalah penelitian kuantitatif. Populasi yang digunakan dalam penelitian ini adalah perusahaan manufaktur yang ada di Indonesia dan terdaftar pada Bursa Efek Indonesia (BEI) periode 2014-2018 yaitu sebanyak 162 perusahaan. Metode yang digunakan dalam penentuan sampel adalah metode purposive sampling.

Tabel 1. Kriteria Pemilihan Sampel

\begin{tabular}{|l|l|}
\hline Keterangan: & Jumlah \\
\hline Perusahaan manufaktur yang terdaftar di BEI & 162 \\
\hline Dikurangi: Perusahaan yang menggunakan mata uang selain rupiah & $(8)$ \\
\hline $\begin{array}{l}\text { Dikurangi: Perusahaan yang tidak mempublikasikan laporan tahunan } \\
\text { berturut-turut selama periode pengamatan 2014-2018 dan data tidak lengkap }\end{array}$ & $(42)$ \\
\hline Dikurangi: Perusahaan yang memiliki laba dan ekuitas negatif & $(76)$ \\
\hline Jumlah sampel & 36 \\
\hline Jumlah sampel pengamatan 36 x 5 tahun & 180 \\
\hline Sampel outlier & $(68)$ \\
\hline Total Sampel Penelitian & 112 \\
\hline
\end{tabular}

\section{Jenis, Sumber, dan Metode Pengumpulan Data}

Penelitian ini menggunakan data sekunder berupa data kuantitatif dari laporan keuangan tahunan (annual report) perusahaan manufaktur yang terdaftar di Bursa Efek Indonesia (BEI) periode 2014-2018. Sumber data sekunder yang digunakan diperoleh dari situs resmi Bursa Efek Indonesia (BEI) yaitu www.idx.co.id. Dalam penelitian ini penulis menggunakan metode dokumenter dalam mengumpulkan data yang dibutuhkan.

\section{Variabel Penelitian dan Pengukuran}

Variabel independen dalam penelitian ini adalah kepemilikan manajerial, kepemilikan institusional, keanggotaan dewan CFO, dan masa jabatan CFO. Kepemilikan manajerial dalam penelitian ini diukur dengan menghitung jumlah kepemilikan saham manajerial dibandingkan dengan jumlah saham yang beredar pada perusahaan dikalikan dengan 100\% . Kepemilikan institusional diukur dengan membandingkan jumlah kepemilikan institusional dengan jumlah saham yang beredar pada perusahaan dikalikan dengan 100\%. Variabel Masa Jabatan CFO diukur dengan menghitung jumlah keseluruhan tahun $\mathrm{CFO}$ yang dihitung pada dari tahun awal CFO menduduki jabatannya.

Masa jabatan CFO atau CFO sebagai direktur insider dikodekan satu (1) jika CFO memiliki masa jabatan yang lama lebih dari satu tahun dan nol (0) jika CFO meiliki masa jabatan yang singkat atau baru menduduki jabatan sebagai CFO. Keanggotaan dewan CFO diukur dengan mengukur jumlah tahun sejak CFO diangkat menjadi anggota dewan dimana jika CFO yang menjadi anggota dewan direksi dinilai dengan (1) begitupun sebaliknya.

Variabel dependen dalam penelitian ini adalah konservatisme akuntansi. Konservatisme dalam penelitian ini diukur dengan melihat kecenderungan dari akumulasi akrual selama beberapa tahun. Apabila perhitungan akrual non operasi minus dan negatif, maka laba digolongkan konservatif dan semakin konservatif. Konservatisme Akuntansi dapat diukur dengan melakukan 
penghitungan akrual non operasi perusahaan. Akrual non operasi (non operating accrual) diperoleh dari pengurangan total akrual dengan operating accrual. Menghitung total akrual dilakukan dengan persamaan sebagai berikut:

$\mathrm{TA}_{\text {it }}=\left(\mathrm{NI}_{\mathrm{it}}+\right.$ Depreciation $)-\mathrm{OCF}$ it

\section{Metode Analisis Data}

Penelitian ini menggunakan program SPSS 22 sebagai alat uji analisis data. Model persamaan regresi linear berganda dalam penelitian ini adalah sebagai berikut:

$$
\mathrm{Y}=\mathrm{a}+\beta 1 \mathrm{KM}+\beta 2 \mathrm{KI}+\beta 3 \mathrm{MJ}+\mathrm{e}
$$

\section{HASIL DAN PEMBAHASAN Analisis Deskriptif}

Tabel 2. Statistik Deskriptif

\begin{tabular}{lrrrrr}
\hline & $\mathrm{N}$ & Minimum & Maximum & \multicolumn{1}{c}{ Mean } & Std. Deviation \\
\hline CONS (Y) & 112 & -.0833 & .1485 & .010288 & .0411111 \\
\hline KM (X1) & 112 & .0000 & 34.5085 & 1.301950 & 4.1067504 \\
\hline KI (X2) & 112 & 1.8214 & 51.4200 & 25.106064 & 13.3700318 \\
\hline MJ (X3) & 112 & 0 & 1 & .66 & .476 \\
\hline Valid N (listwise) & 112 & & & & \\
\hline
\end{tabular}

Sumber: Hasil Olah Data SPSS 2020

Berdasarkan Tabel 2 diatas dapat diketahui bahwa sampel penelitian (N) berjumlah 112 sampel untuk setiap variabel yang diteliti. Variabel Konservatisme Akuntansi (CONS) mempunyai nilai terendah sebesar $-0,0833$, nilai tertinggi sebesar 0,1485 , mean sebesar 0,010288 dan standar deviasinya sebesar 0, 0411111. Variabel Kepemilikan Manajerial (KM) mempunyai nilai terendah sebesar 0,0000, nilai tertinggi sebesar 34,5085, mean sebesar 1,301950 dan standar deviasinya sebesar 4,1067504. Variabel Kepemilikan Institusional (KI) mempunyai nilai terendah sebesar 1,8214, nilai tertinggi sebesar 51,4200, mean sebesar 25,106064 dan standar deviasinya sebesar 13,3700318. Variabel Masa Jabatan (MJ) mempunyai nilai terendah sebesar 0, nilai tertinggi sebesar 1, mean sebesar 0,66 dan standar deviasinya sebesar 0,476 .

\section{Asumsi Klasik Uji Normalitas}

\begin{tabular}{llr}
\hline \multicolumn{3}{c}{ Tabel 3. Hasil Normalitas } \\
\hline & & \multicolumn{1}{c}{ Unstandardized Residual } \\
\hline $\mathrm{N}$ & \multicolumn{1}{c}{ Mean } & 112 \\
\cline { 2 - 3 } Normal & & .0000000 \\
Parameters ${ }^{\mathrm{a}, \mathrm{b}}$ & Std. Deviation & .03914516 \\
\hline Most Extreme & Absolute & .082 \\
\cline { 2 - 3 } Differences & Positive & .082 \\
\cline { 2 - 3 } & Negative & -.057 \\
\hline Test Statistic & & .082 \\
\hline Asymp. Sig. (2-tailed) & .061
\end{tabular}


a. Test distribution is Normal.

b. Calculated from data.

Sumber: Hasil Olah SPSS 2020.

Berdasarkan Tabel 3 diketahui nilai signifikansi (Asymp. Sig. 2-tailed) sebesar 0,061 (0,061 > 0,05) maka dapat disimpulkan bahwa seluruh variabel dalam penelitian ini memiliki nilai signifikansi $>0,05$ yang artinya data telah terdistribusi dengan normal.

\section{Uji Multikolinearitas}

Tabel 4. Hasil Uji Multikolinearitas

\begin{tabular}{lcr}
\hline & \multicolumn{3}{c}{ Collinearity Statistics } \\
\cline { 2 - 3 } Model & \multicolumn{2}{c}{ Tolerance } \\
\hline (Constant) & \multicolumn{2}{c}{} \\
\hline KM $(\mathrm{X} 1)$ & .962 & 1.040 \\
\hline KI (X2) & .972 & 1.029 \\
\hline MJ (X3) & .989 & 1.011 \\
\hline
\end{tabular}

a. Dependent Variable: CONS (Y)

Sumber: Hasil Olah SPSS 2020

Berdasarkan Tabel 4 di atas dapat diketahui bahwa nilai tolerance untuk variabel Konservatisme Akuntansi (CONS), Kepemilikan Manajerial (KM), Kepemilikan Institusional (KI), dan Masa Jabatan CFO (MJ) menunjukkan nilai lebih besar dari 0,10. Hasil perhitungan VIF juga menunjukkan hal yang sama yaitu tidak ada satupun variabel independen yang memiliki nilai VIF lebih dari 10. Maka, dapat disimpulkan tidak terjadi multikolinearitas antar variabel independen dalam penelitian ini.

\section{Uji Heteroskedastisitas}

Tabel 5. Hasil Uji Heteroskedastisitas

\begin{tabular}{|c|c|c|c|c|c|}
\hline \multirow[b]{2}{*}{ Model } & \multicolumn{2}{|c|}{$\begin{array}{l}\text { Unstandardized } \\
\text { Coefficients }\end{array}$} & \multirow{2}{*}{$\begin{array}{l}\text { Standardized } \\
\text { Coefficients } \\
\text { Beta }\end{array}$} & \multirow[b]{2}{*}{$\mathrm{T}$} & \multirow[b]{2}{*}{ Sig. } \\
\hline & B & Std. Error & & & \\
\hline (Constant) & .032 & .010 & & 3.349 & .001 \\
\hline KM (X1) & -.001 & .001 & -.054 & -.578 & .564 \\
\hline KI (X2) & -.001 & .000 & .291 & 3.133 & .002 \\
\hline $\mathrm{MJ}(\mathrm{X} 3)$ & .002 & .008 & .023 & .249 & .804 \\
\hline
\end{tabular}

a. Dependent Variable: CONS (Y)

Sumber: Hasil Olah Data 2020

Berdasarkan Tabel 5 menunjukkan nilai signifikansi pada variabel Konservatisme Akuntansi (CONS), Kepemilikan Manajerial (KM), Kepemilikan Institusional (KI), dan Masa Jabatan CFO lebih besar dari 0,05 sehingga dapat disimpulkan bahwa tidak terjadi masalah heteroskedastisitas dalam penelitian ini. 


\section{Uji Autokorelasi}

Tabel 6. Hasil Uji Autokorelasi

\begin{tabular}{|c|c|c|c|c|c|}
\hline Model & $\mathrm{R}$ & $\begin{array}{c}\mathrm{R} \\
\text { Square }\end{array}$ & $\begin{array}{l}\text { Adjusted } \\
\text { R Square }\end{array}$ & $\begin{array}{l}\text { Std. Error of the } \\
\text { Estimate }\end{array}$ & Durbin-Watson \\
\hline 1 & $.306^{\mathrm{a}}$ & .093 & .068 & .0396851 & 1.851 \\
\hline \multicolumn{6}{|c|}{ a. Predictors: (Constant), MJ (X3), KI (X2), KM (X1) } \\
\hline \multicolumn{6}{|c|}{$\begin{array}{l}\text { b. Dependent Variable: CONS }(\mathrm{Y}) \\
\text { Sumber: Hasil Olah SPSS } 2020\end{array}$} \\
\hline
\end{tabular}

Berdasarkan Tabel 6 di atas dapat diketahui bahwa nilai Durbin Watson (DW) ialah sebesar 1.851 yang berarti berada diantara dU sebesar 1.747 dan 4-dU sebesar 2.253 sehingga dapat disimpulkan bahwa tidak terjadi autokorelasi atau tidak ada korelasi antara data berdasarkan urutan waktu dan model untuk penelitian ini dapat diterima.

\section{Uji Kelayakan Model}

\section{Uji Koefisiensi Determinasi $\left(\mathbf{R}^{2}\right)$}

Tabel 7. Hasil Uji Koefisiensi Determinasi $\left(\mathbf{R}^{2}\right)$

\begin{tabular}{lccccr}
\hline $\begin{array}{l}\text { Mode } \\
1\end{array}$ & $\mathrm{R}$ & $\mathrm{R}$ Square & $\begin{array}{c}\text { Adjusted R } \\
\text { Square }\end{array}$ & $\begin{array}{c}\text { Std. Error of } \\
\text { the Estimate }\end{array}$ & Durbin-Watson \\
\hline 1 & $.306^{\mathrm{a}}$ & .093 & .068 & .0396851 & 1.851 \\
\hline a. Predictors: (Constant), MJ (X3), KI (X2), KM (X1) & \\
\hline \multicolumn{5}{l}{ b. Dependent Variable: CONS (Y) } \\
Sumber: Hasil Olah SPSS 2020 \\
\hline
\end{tabular}

Berdasarkan Tabel 7 di atas menunjukkan bahwa nilai R Square sebesar 0,093 artinya variabel konservatisme akuntansi dapat dijelaskan oleh variabel kepemilikan manajerial, kepemilikan institusional dan masa jabatan CFO sebesar 9,3\%, sedangkan sebesar 90,7\% dipengaruhi oleh variabel lain yang tidak diteliti.

\section{Pengujian Hipotesis}

\section{Uji Statistik F}

Tabel 8. Hasil Uji Statistik F

\begin{tabular}{lrrrrr} 
Model & Sum of Squares & Df & Mean Square & F & \multicolumn{1}{l}{ Sig. } \\
\hline Regression & .018 & 3 & .006 & 3.707 & $.014^{\mathrm{b}}$ \\
\hline Residual & .170 & 108 & .002 & & \\
\hline Total & .188 & 111 & & & \\
\hline a. Dependent Variable: CONS (Y) & & & & \\
\hline
\end{tabular}

Berdasarkan hasil uji statistik F yang disajikan dalam Tabel 8 di atas menunjukkan bahwa nilai sig $<0,05$, sehingga dapat ditarik kesimpulan bahwa variabel kepemilikan manajerial, kepemilikan institusional dan masa jabatan CFO secara simultan berpengaruh terhadap konservatisme akuntansi. 


\section{Uji Statistik t}

Tabel 9. Hasil Uji Statistik t

\begin{tabular}{lcccrcr}
\hline & \multicolumn{2}{c}{$\begin{array}{c}\text { Unstandardized } \\
\text { Coefficients }\end{array}$} & \multicolumn{2}{c}{$\begin{array}{c}\text { Standardized } \\
\text { Coefficients }\end{array}$} & & \\
Statistik tModel & $\mathrm{B}$ & Std. Error & Beta & t & Sig. \\
\cline { 2 - 5 } (Constant) & .032 & .010 & & 3.349 & .001 \\
\hline KM (X1) & -.001 & .001 & -.054 & -.578 & .564 \\
\hline KI (X2) & .001 & .000 & .291 & 3.133 & .002 \\
\hline MJ (X3) & .002 & .008 & .023 & .249 & .804
\end{tabular}

a. Dependent Variable: CONS (Y)

Sumber: Hasil Olah SPSS 2020

Berdasarkan hasil pengujian statistik t pada Tabel XX di atas maka dapat diuraikan sebagai berikut:

1) Pengujian Hipotesis 1

Berdasarkan hasil pengujian statistik t pada Tabel XV variabel kepemilikan manajerial memiliki koefisien regresi (beta) sebesar -0,054 dan nilai sig sebesar 0,564. Tingkat signifikansi variabel kepemilikan manajerial lebih besar dari alpha 0,05 sehingga dapat disimpulkan bahwa kepemilikan manajerial tidak berpengaruh terhadap konservatisme akuntansi. Dengan demikian maka hipotesis pertama $(\mathrm{H} 1)$ yang menjelaskan bahwa kepemilikan manajerial berpengaruh positif terhadap konservatisme akuntansi ditolak.

2) Pengujian Hipotesis 2

Berdasarkan hasil pengujian statistik t pada Tabel XV variabel kepemilikan institusional memiliki koefisien regresi (beta) sebesar 0,291 dan nilai sig sebesar 0,002. Tingkat signifikansi variabel kepemilikan institusional lebih kecil dari alpha 0,05 sehingga dapat disimpulkan bahwa kepemilikan institusional berpengaruh terhadap konservatisme akuntansi. Maka, hipotesis kedua (H2) yang menjelaskan bahwa kepemilikan institusional berpengaruh positif terhadap konservatisme akuntansi diterima.

3) Pengujian Hipotesis 3

Berdasarkan hasil pengujian statistik t pada Tabel XV variabel masa jabatan CFO memiliki koefisien regresi (beta) sebesar 0,023 dan nilai sig sebesar 0,804. Tingkat signifikansi variabel kepemilikan manajerial lebih besar dari alpha 0,05 sehingga dapat disimpulkan bahwa masa jabatan CFO tidak berpengaruh terhadap konservatisme akuntansi. Dengan demikian maka hipotesis ketiga (H3) yang menjelaskan bahwa masa jabatan CFO berpengaruh positif terhadap konservatisme akuntansi ditolak.

\section{PEMBAHASAN}

\section{Pengaruh Kepemilikan Manajerial Terhadap Konservatisme Akuntansi Pada Perusahaan Manufaktur}

Hasil analisis statistik dalam penelitian ini menunjukkan bahwa kepemilikan manajerial berpengaruh negatif dan tidak signifikan terhadap konservatisme akuntansi pada perusahaan manufaktur di Indonesia. Semakin tinggi tingkat kepemilikan manajerial yang ada pada perusahaan maka semakin rendah tingkat konservatisme akuntansi yang diterapkan oleh perusahaan. Hubungan negatif antara kepemilikan manajerial dan penerapan akuntasi yang 
konservatif disebabkan karena kepemilikan saham yang lebih besar oleh manajerial akan bisa mengimbangi pemegang saham dari luar. Hal ini menimbulkan adanya kecenderungan dari pihak manajer melalui kepemilikan ekuitas tinggi sehingga akan memilih untuk mengurangi penerapan akuntansi yang konservatif untuk mencegah terjadinya penurunan harga saham (Fitri, 2017).

Hasil yang negatif ini juga menunjukkan bahwa jika kepemilikan manajerial dalam perusahaan itu tinggi maka pihak manajemen akan cenderung tidak terlalu menerapkan akuntansi yang konservatif. Hal ini disebabkan karena pihak manajerial akan berusaha menikmati cadangan laba yang ditunda pengakuannya untuk kepentingan pribadi, hasil ini sejalan dengan penelitian yang dilakukan oleh Ursula dan Adhivinna, (2018). Hasil penelitian ini bertolak belakang dengan penelitian yang dilakukan oleh (Pambudi, 2017) dan Putra, dkk (2019) bahwa kepemilikan manajerial berpengaruh positif terhadap konservatisme akuntansi. Penelitian tersebut menyimpulkan bahwa dengan cara melibatkan pihak manajemen dalam kepemilikan suatu saham perusahaan, maka dapat mengurangi tindakan oportunis manajemen sehingga akan cenderung untuk menerapkan prinsip akuntansi konservatif.

\section{Pengaruh Kepemilikan Institusional Terhadap Konservatisme Akuntansi Pada Perusahaan Manufaktur}

Hasil analisis statistik dalam penelitian ini menunjukkan bahwa kepemilikan institusional berpengaruh positif dan signifikan terhadap konservatisme akuntansi pada perusahaan manufaktur di Indonesia. Pengaruh ini menunjukkan bahwa peningkatan atau penurunan kepemilikan institusional akan searah dengan peningkatan atau penurunan tingkat konservatisme akuntansi perusahaan. Kepemilikan institusional berarti kepemilikan saham oleh pihak institusi lain. Semakin tinggi tingkat kepemilikan institusional maka semakin kuat tingkat pengawasan dan pengendalian yang dilakukan oleh pihak eksternal perusahaan untuk menekan perilaku oportunis manajemen (Putra dkk, 2019).

Hasil penelitian ini konsisten dengan penelitian yang dilakukan oleh Alkurdi et al., (2017) bahwa kepemilikan institusional memiliki pengaruh positif terhadap konservatisme akuntansi. Perusahaan yang memiliki tingkat kepemilikan institusional yang tinggi memiliki pengawasan yang intensif terhadap perusahaan sehingga lebih memperhatikan kinerja dan keberlanjutan perusahaan. Hasil penelitian ini bertolak belakang dengan penelitian yang dilakukan oleh Risdiyani \& Kusmuriyanto (2015) dan Tazkiya (2019) bahwa kepemilikan institusional berpengaruh negatif terhadap konservatisme akuntansi. Penelitian ini menyimpulkan bahwa kepemilikan institusional yang tinggi akan mengurangi tingkat penerapan konservatisme akuntansi pada perusahaan.

\section{Pengaruh Masa Jabatan CFO Terhadap Konservatisme Akuntansi Pada Perusahaan Manufaktur}

Hasil analisis statistik dalam penelitian ini menunjukkan bahwa masa jabatan CFO berpengaruh positif dan tidak signifikan terhadap konservatisme akuntansi pada perusahaan manufaktur di Indonesia. Semakin lama masa jabatan seorang CFO maka semakin tinggi juga tingkat penerapan konservatisme akuntansi pada perusahaan. CFO dengan masa jabatan lebih lama memiliki pengetahuan yang lebih mengenai konteks pekerjaan dan perusahaan secara spesifik, sehingga akan cenderung lebih berkomitmen untuk membuat laporan keuangan yang lebih konservatif (Muttakin et al., 2019).

Hasil penelitian ini konsisten dengan penelitian yang dilakukan oleh Muttakin et al., (2019) bahwa dengan masa jabatan CFO yang lama maka CFO akan lebih memahami karakteristik dan kondisi perusahaan. Dengan begitu CFO lebih memiliki keahlian dan pengalaman sehingga 
mempengaruhi peningkatan kualitas pelaporan keuangan melalui penerapan konservatisme akuntansi dalam menyusun laporan keuangan. Penelitian ini bertolak belakang dengan penelitian yang dilakukan oleh Geiger, M., \& North, D. (2008) dimana hasil penelitiannya menunjukkan penurunan yang signifikan dalam penerapan konservatisme akuntansi dalam pelaporan keuangan ketika CFO baru ditunjuk atau ketika CFO memiliki masa jabatan yang singkat.

\section{SIMPULAN, KETERBATASAN, DAN SARAN \\ Simpulan}

Berdasarkan hasil analisis data pengaruh kepemilikan manajerial, kepemilikan institusional dan masa jabatan CFO terhadap konservatisme akuntansi pada perusahaan manfaktur yang terdaftar di Bursa Efek Indonesia (BEI) tahun 2014-2018, maka dapat disimpulkan sebagai berikut:

1. Kepemilikan manajerial berpengaruh negatif dan tidak signifikan terhadap konservatisme akuntansi pada perusahaan manufaktur yang terdaftar di Bursa Efek Indonesia (BEI) tahun 2014-2018.

2. Kepemilikan Institusional berpengaruh positif dan signifikan terhadap konservatisme akuntansi pada perusahaan manufaktur yang terdaftar di Bursa Efek Indonesia (BEI) tahun 2014-2018.

3. Masa jabatan CFO berpengaruh positif dan tidak signifikan terhadap konservatisme akuntansi pada perusahaan manufaktur yang terdaftar di Bursa Efek Indonesia (BEI) tahun 2014-2018.

\section{Keterbatasan}

Penelitian ini memiliki keterbatasan yang dapat dijadikan acuan untuk penelitian selanjutnya agar memperoleh hasil yang lebih baik. Keterbatasan dalam penelitian ini adalah sebagai berikut:

1. Pada penelitian ini hanya memiliki nilai R Square sebesar 9,3\%. Hal tersebut menunjukkan bahwa terdapat variabel lain yang tidak digunakan dalam penelitian ini yang memiliki pengaruh besar terhadap konservatisme akuntansi.

2. Pada penelitian ini hanya menggunakan tahun penelitian 2014-2018 dan terbatas pada perusahaan manufaktur saja, sehigga hasilnya tidak bisa menggeneralisasikan perusahaan yang ada di Indonesia.

\section{Saran}

Berdasarkan kesimpulan dan keterbatasan penelitian di atas maka dapat diberikan saran sebagai berikut:

1. Bagi Perusahaan

Bagi perusahaan disarankan lebih cermat dan berhati-hati dalam menerapkan konsep konservatisme agar tidak menyimpang dari standar akuntansi yang berlaku.

2. Bagi penelitian selanjutnya

a. Untuk penelitian selanjutnya disarankan untuk menambah variabel lain yang mungkin berpengaruh terhadap konservatisme akuntansi seperti proporsi komisaris independen, political cost, dan lainnya.

b. Bagi peneliti selanjutnya disarankan untuk memperpanjang tahun penelitian dan memperluas sampel penelitian, misalnya dengan melakukan penelitian disemua sektor perushaan, sehingga hasil penelitian dapat menggambarkan semua sektor perusahaan yang ada di Indonesia. 


\section{DAFTAR PUSTAKA}

Aier, J. K., Comprix, J., Gunlock, M. T., \& Lee, D. (2005). The financial expertise of CFOs and accounting restatements. Acc. Horizons.

Alfian, A., \& Sabeni, A. (2013). Analisis Faktor-Faktor Yang Berpengaruh Terhadap Pemilihan Konservatisme Akuntansi. Diponegoro Journal of Accounting, 2(2008), 123-132.

Ali, A., \& Zhang, W. (2015). CEO tenure and earnings management. Journal of Accounting and Economics, 59(1), 60-79. https://doi.org/10.1016/j.jacceco.2014.11.004

Alkurdi, A., Al-nimer, M., \& Dabaghia, M. (2017). Accounting Conservatism and Ownership Structure Effect: Evidence from Industrial and Financial Jordanian Listed Companies. International Journal of Economics and Financial Issue, 7(2), 608-619.

Ardiyansyah, M. (2014). Pengaruh Corporate Governance, Leverage dan Profitabilitas terhadap Manajemen Laba. Universitas Maritim Raja Ali Haji 1, 1-29.

Astuti, D. S. . (2007). Analisis Faktor-Faktor Yang Mempengaruhi Motivasi Manajemen Laba Di Seputar Right Issue. Jurnal Ilmiah Akuntansi Dan Bisnis, 1-24.

Atmaja, L. S. (2008). Teori dan Praktek Manajemen Keuangan. penerbit Andi.

Ball, R., \& Shivakumar, L. (2005). Earnings quality in UK private firms: Comparative loss recognition timeliness. Journal of Accounting and Economics, 39(1), 83-128. https://doi.org/10.1016/j.jacceco.2004.04.001

Balsam, S., Krishnan, J., \& Yang, J. . (2003). Auditor Industry Specialization and Earnings Quality,Auditing. A Journal of Practice \& Theory.

Basu, S. (1997). The conservatism principle and the asymmetric timeliness of earnings 1 Sudipta. Journal of Accounting and Economics, 24, 3-37.

Beasley, M. S. (1996). An emperical analysis of relation between directors and financial fraud. In The Accounting Review (Vol. 71, Issue 4, pp. 443-465).

Beaver, W. H., \& Ryan, S. G. (2000). Biases and Lags in Book Value and Their Effects on the Ability of the Book-to-Market Ratio to Predict Book Return on Equity. Journal of Accounting Research, 38(1), 127. https://doi.org/10.2307/2672925

Brilianti, D. (2013). Pengaruh Kepemilikan Manajerial , Kepemilikan Institusional, Leverage, dan Komite Audit terhadap Konservatisme Akuntansi. Universitas Negeri Semarang.

Delima.P, G. (2018). Pengaruh kepemilikan manajerial, proporsi komisaris independen, dan Political Cost terhadap Konservatisme Akuntansi. Universitas Islam Indonesia Yogyakarta.

Deviyanti, D. artika. (2012). Analisi Faktor-Faktor yang Mempengaruhi Penerapan Konservatisme dalam Akuntansi. Universitas Diponegoro Semarang.

Fama, E. F., \& Jensen, M. C. (1983). Separation of Ownership and Control. The Journal of Law and Economics, 26(2), 301-325. https://doi.org/10.1086/467037

Fitri, G. A. (2017). Analisis Pengaruh Financial Distress, Leverage dan Kepemilikan Manajerial Perusahaan Terhadap Penerapan Konservatisme dalam Akuntansi. Jurnal Ekonomi Dan Akuntansi Universitas Negeri Padang.

Geiger, M., North, D. (2008). Does hiring a new CFO change things? An investigation of changes in discretionary accruals. Account Rev, 81, 781-809.

Geiger, M. A., Lennox, C. S., \& North, D. S. (2008). The hiring of accounting and finance officers from audit firms: How did the market react? Review of Accounting Studies, 13(1), 55-86. https://doi.org/10.1007/s11142-007-9047-y

Ghozali, I. (2018). Aplikasi Analisis Multivariet dengan Program SPSS. Universitas Diponegoro. Ghozali, Imam, \& Anis, C. (2007). Teori Akuntansi. Badan Penerbit Universitas Diponegoro. 
Haniati, S., \& Fitriany. (2010). Pengaruh Konservatisme terhadap Asimetri Informasi dengan Menggunakan Beberapa Model Pengukuran Konservatisme. Simposium Nasional Akuntansi XIII Purwokerto.

Harahap, S. S. (2008). Teori Akuntansi. Rajawali Pers.

Hayn, C. K., \& Givoly, D. (2000). The Changing time-series properties of earning, cash flows and accrual: Has financial reporting become more conservative? Journal of Accounting and Economics, 29, 287-320.

Jaya, T. E., Arafat, M. Y., \& Kartika, D. (2012). Corporate Governance, Konservatisme Akuntansi, dan Tax Avoidance. Prosiding Simposium Nasional Perpajakan 4 CORPORATE, $66,37-39$.

Jensen, M. C., \& Meckling, W. H. (1976). Theory of the Firm: Managerial Behavior, Agency Cost and Ownership Structure. Journal of Financial Economics, 3, 305-360. https://doi.org/http://dx.doi.org/10.1016/0304-405X(76)90026-X

Lestari. (2017). Pengaruh Kepemilikan Institusional Dan Struktur Modal Terhadap Nilai Perusahaan. Jurnal Riset Manajemen Dan Bisnis (JRMB) Fakultas Ekonomi UNIAT, 2(September), 293-306. https://doi.org/10.36226/jrmb.v2is1.62

Mamesah, M., Saerang, D. P. E., \& Lambey, L. (2016). Faktor-Faktor Yang Mempengaruhi Penerapan Konservatisme Akuntansi. Accountability, 5(2), 237. https://doi.org/10.32400/ja.14438.5.2.2016.237-248

Milana, E., \& Maldaon, I. (2015). Managerial characteristics and its impact on organizational performance: Evidence from syria. Business: Theory and Practice, 16(2), 212-221. https://doi.org/10.3846/btp.2015.486

Milbourn, T. T. (2003). CEO Reputation and Stock-Based Compensation. Journal of Financial Economics, 68(2), 233-262. https://doi.org/10.1016/S0304-405X(03)00066-7

Mobbs, S. (2011). Internal Financial Expertise on the Board: Implications for Corporate Financial Policy. SSRN Electronic Journal, April. https://doi.org/10.2139/ssrn.1782959

Morck, R., Shleifer, A., \& Vishny, R. W. (1989). Management Ownership and Market Valuation. North-Holland Mathematics Studies, 157(C), 275-380. https://doi.org/10.1016/S03040208(08)70243-3

Muttakin, M. B., Khan, A., \& Tanewski, G. (2019). CFO Tenure, CFO Board Membership and Accounting Conservatism. Journal of Contemporary Accounting and Economics, 15(3), 100165. https://doi.org/10.1016/j.jcae.2019.100165

Nasir, A., Ilham, E., \& Yusniati. (2014). Pengaruh Struktur Kepemilikan Manajerial, Risiko Litigasi, Likuidasi, dan Political Cost terhadap Konservatisme Akuntansi. Jurnal Ekonomi, $22,138-150$.

Nazaruddin, I., \& Basuki, A. T. (2017). Analisis Statistik dengan SPSS. Danisa Media.

Noviantari, N., \& Ratnadi, N. (2015). Pengaruh Financial Distress, Ukuran Perusahaan, Dan Leverage Pada Konservatisme Akuntansi. E-Jurnal Akuntansi, 11(3), 646-660.

Oliver, J. (2013). . Journal of Chemical Information and Modeling, 53(9), 1689-1699. https://doi.org/10.1017/CBO9781107415324.004

Padmawati, I., \& Fachrurrozie. (2015). Pengaruh Mekanisme Good Corporate Governance Dan Kualitas Audit Terhadap Tingkat Konservatisme Akuntans. Accounting Analysis Journal.

Pambudi, J. E. (2017). Pengaruh Kepemilikan Manajerial Dan Debt Covenant Terhadap Konservatisme Akuntansi. Competitive Jurnal Akuntansi Dan Keuangan, 1(1), 87. https://doi.org/10.31000/competitive.v1i1.109 
Putra, I. G. B. N. P., Sari, P. A. M. P., \& Larasdiputra, G. D. (2019). Pengaruh Kepemilikan Institusional Dan Kepemilikan Manajerial Pada Konservatisme Akuntansi. E-Journal Warmadewa., 18(1), 41-51. https://doi.org/10.22225/we.18.1.991.41-51

R.Padmawati, I., \& Fachrurrozie. (2015). Pengaruh Mekanisme Good Corporate Governance Dan Kualitas Audit Terhadap Tingkat Konservatisme Akuntansi. Accounting Analysis Journal, 4(1), 1-11. https://doi.org/10.15294/aaj.v4i1.7810

Rachmawati, A., \& Triatmoko, H. (2007). Ananlisis Faktor-Faktor yang Mempengaruhi Kualitas Laba dan Nilai Perusahaan. Simposium Nasional Akuntansi XIII Universitas Sebelas Maret, $1-26$.

Risdiyani, F., \& Kusmuriyanto. (2015). Analisis Faktor-Faktor Yang Mempengaruhi Penerapan Konservatisme Akuntansi. Accounting Analysis Journal, 4(3), 1-10. https://doi.org/10.15294/aaj.v4i3.8305

Sinambela, M. O. E., \& Almilia, L. S. (2018). Faktor-faktor yang mempengaruhi konservatisme akuntansi. Jurnal Ekonomi Dan Bisnis, 21(2), 289-312. https://doi.org/10.24914/jeb.v21i2.1788

Soewardjono. (2005). Teori Akuntansi (Edisi 3). BPFE.

Sudana, I. M. (2011). Manajemen Keuangan PerusahaanTeori dan Praktik. Erlangga.

Sugiyono. (2013). Metode Penelitian Pendidikan (Pendekatan kualitatif, kuantitatif, dan R\&D). Alfabeta.

Tazkiya, H. (2019). Pengaruh Karakteristik Perusahaan, Tata Kelola Korporat, dan Pensiun CEO terhadap Konservatisme Akuntansi. Universitas Islam Indonesia Yogyakarta.

Ursula, E. A., \& Adhivinna, V. V. (2018). Pengaruh Kepemilikan Manajerial Ukuran Perusahaan, Konservatisme Akuntansi. Jurnal Akuntansi Universitas PGRI Yogyakarta, 6(2), 194-206. https://doi.org/10.24964/ja.v6i2.643

Wardhani, R. (2008). Tingkat Konservatisme Akuntansi di Indonesia dan Hubungannya dengan Karakteristik Dewan sebagai Salah Satu Mekanisme Corporate Governance. Prosiding Simposium Nasional Akuntansi XI, Pontianak (23-24 Juli), XI, 1-26. https://doi.org/10.1017/CBO9781107415324.004

Watts, R. L. (2003). Modern Electrochemistry: An introduction to an interdisciplinary area. Accounting Horizons: September 2003, 17(3), 207-221.

Westphal, J. D. (1999). Collaboration in the Boardroom: Behavioral and Performance Consequences of CEO-Board Social Ties. Academy of Management Journal, 42(1), 7-24. https://doi.org/10.5465/256871

Wulansari, C. A., \& Riduwan, A. (2014). Pengaruh Struktur Kepemilikan, Kontrak Hutang dan Kesempatan Tumbuh pada Konservatisme Akuntansi. Jurnal Ilmu \& Riset Akuntansi, 3(8), $1-18$.

Yuniat, M., Raharjo, K., \& Oemar, A. (2016). Pengaruh Kebijakan Deviden, Kebijakan Hutang, Profitabilitas, dan Struktur Kepemilikan terhadap Nilai Perusahaan. Journal Of Accounting, 2(2).

Zulkarnain, P. (2016). Pengaruh Leverage, Kepemilikan Manajerial, dan Growth terhadap Kebijakan Deviden. IOSR Journal of Economics and Finance, 3(1), 56. https://doi.org/https://doi.org/10.3929/ethz-b-000238666 